Dagmara Gluszek-Szafraniec

UNIWERSYTET ŚLĄSKI W KaTOWICACH, Instytut Nauk Politycznych i Dziennikarstwa

ZaKŁad Komunikowania MięDzynarodowego

I Systemów Medialnych

DAGAGLUSZEK@YAHOO.DE

\title{
POLITYKA MEDIALNA W KATALONII I KRAJU BASKÓW JAKO NARZĘDZIE ROZWOJU TOŻSAMOŚCI REGIONALNYCH
}

\section{Wprowadzenie}

Procesy demokratyzacji w Hiszpanii po 1975 r. doprowadziły do uznania odrębności kulturowej i językowej mieszkańców poszczególnych regionów. Zmiany polityczne stały się katalizatorem do uzewnętrzniania swoistych cech wielu grup narodowych zamieszkujących Hiszpanię. Proces ten dotyczył zarówno spraw politycznych, społecznych, jak i ekonomicznych czy kulturowych. Przemiany demokratyczne wpływały na oczekiwania dotyczące zmiany statusu wspomnianych grup, dotychczas dyskryminowanych lub marginalizowanych $\mathrm{w}$ społeczeństwie hiszpańskim ze względu na różnice kulturowo-językowe. W szczególności kwestia ta odnosiła się do trzech tzw. regionów historycznych, tj. Katalonii, Kraju Basków i Galicji.

Celem niniejszego artykułu jest przedstawienie dwóch regionalnych systemów medialnych oraz polityki medialnej w Katalonii i Kraju Basków ${ }^{1}$. Specyfika analizowanych przypadków wynika z odmienności kulturowych

1 Do regionów historycznych zalicza się pierwotnie Katalonię, Kraj Basków i Galicję, ale ten trzeci region od czasu uzyskania autonomii ma problem z prowadzeniem samodzielnej polityki regionalnej, która wzmacniałaby status języka galicyjskiego czy sprzyjała tworzeniu się odrębnego systemu medialnego. W Galicji można wręcz obserwować proces degalicyzacji, polegający na wypieraniu języka z przestrzeni publicznej regionu [Por. Lorenzo Suárez, Ramallo, Casares Berg 2008]. 
i językowych wymienionych wspólnot autonomicznych. Można tutaj postawić tezę, że w debacie na temat separatyzmów regionalnych w Hiszpanii istotny głos należy do regionalnych mediów, zarówno prywatnych, jak i publicznych. Wynika to bowiem z założenia, że media wywierają potencjalny wpływ na odbiorców przez własną politykę redakcyjną [Pisarek 2007: 62] lub naciski polityczne ze strony partii rządzących w regionie, które decydują o finansowaniu mediów publicznych, ale także prywatnych przez system subwencji. Polityka medialna rządów regionalnych Katalonii i Kraju Basków skoncentrowała się więc na stworzeniu odrębnego systemu medialnego dla własnego regionu, by dzięki mediom kształtować opinię publiczną sprzyjającą tendencjom separatystycznym. Pytania, jakie należy postawić na wstępie analizy, dotyczą tego, jak działają współczesne systemy mediów na poziomie regionalnym w Katalonii i Kraju Basków, na ile działania rządów mają odzwierciedlenie w sytuacji mediów regionalnych, czy rozwój mediów zależy od wsparcia instytucjonalnego, czy też jest wyłącznie wynikiem inicjatywy oddolnej oraz czy polityka medialna wymienionych wspólnot autonomicznych odgrywa rolę w kształtowaniu regionalnych systemów medialnych, które będą służyły określonej sprawie?

\section{Kontekst historyczny polityki medialnej regionów}

Polityka medialna we wspólnotach autonomicznych, których ludność w największym stopniu odróżniała się językowo i kulturowo od pozostałych mieszkańców Hiszpanii, rozpoczęła się na początku lat osiemdziesiątych XX w. Oczywiście nie była ona jedynym czynnikiem, który miał wzmacniać tożsamość regionalną na danym terytorium. Była raczej narzędziem wspomagającym system edukacji, propagując wartości związane z regionalną tożsamością, a także język i kulturę w mediach. Działania rządów regionalnych były ukierunkowane na podkreślanie różnorodności grup zamieszkujących poszczególne wspólnoty autonomiczne. Polityka ta wynikała z podziałów historycznych i tradycji mieszkańców Półwyspu Iberyjskiego.

Społeczeństwo Hiszpanii można określić mianem społeczeństwa zróżnicowanego kulturowo, ze względu na fakt, że występują w nim zinstytucjonalizowane zbiorowości, które posiadają odmienne kultury, podtrzymywane i rozwijane w sposób instytucjonalny [Sadowski 2011: 22]. W Konstytucji Hiszpanii z 1978 r. ustanawia się tę różnorodność w art. 3, uznając bogactwo języków jako dziedzictwo kulturowe, które winno być szanowane. W art. 2 gwarantuje się prawo do autonomii narodowości i re- 
gionów wchodzących w skład państwa hiszpańskiego, z zachowaniem zasady solidarności i jedności narodu hiszpańskiego. W myśl koncepcji społeczeństwa zróżnicowanego kulturowo, dyskusyjny może być status kultury dominującej. Wydaje się, że taką rolę w Hiszpanii odgrywa kultura kastylijska ${ }^{2}$, charakteryzująca głównie region Kastylii-La Manchy czy Kastylii -Leonu. Wpływowi tej kultury częściowo uległy także regiony Aragonii, Estremadury, Wspólnoty Walencji i Murcji (tzw. regiony skastylizowane) ${ }^{3}$. Natomiast kultura baskijska, katalońska, galicyjska, andaluzyjska, nawarska, kanaryjska czy balearska stanowiłyby raczej kultury mniejszościowe ze specjalnym statusem, choć Konstytucja stanowi, że żaden ze statutów autonomicznych nie może prowadzić do uprzywilejowania gospodarczego czy społecznego którejkolwiek ze wspólnot (art. 138 pkt. 2), [Por. Wojcieszak, Głuszek-Szafraniec 2011: 109].

Omawiając kwestię tożsamości regionalnych Hiszpanii należy odwołać się do pojęcia nacjonalizmu, które w przypadku tego kraju nabiera szczególnego znaczenia. Określenie to, we współczesnym rozumieniu wysoce pejoratywne, najczęściej używane jest w odniesieniu do przeciwników jedności narodowej, czy też jedni hiszpańskiej. Jak pisze Maja Biernacka: [...] nacjonalista nigdy nie jest autodefinicją, jest natomiast epitetem wobec innych, przeciwstawnych ideowo w swych narodowych roszczeniach tożsamościowych [Biernacka 2010: 10].

Dlatego też w przypadku Hiszpanii wszelkie procesy konstruowania tożsamości narodowej mogą być rozpatrywane albo w kontekście españolismo, czyli nacjonalizmu hiszpańskiego i zwolenników jedności państwa, albo w kontekście nacjonalizmów peryferyjnych [Biernacka 2010: 10] lub mikronacjonalizmów, odnoszących się do dążeń separatystycznych takich regionów jak Katalonia czy Kraj Basków [por. Nguyen 1998]. Roszczenia emancypacyjne powodują, że społeczeństwo hiszpańskie nie powinno być postrzegane jako pewna kulturowa jedność, ale właśnie jako społeczeństwo zróżnicowane kulturowo.

2 Oficjalnym językiem Hiszpanii jest właśnie język kastylijski. Istnieją także inne języki o tym statusie, jak baskijski, kataloński czy galicyjski, ale ich używanie regulują poszczególne statuty autonomiczne regionów, których ludność posługuje się również innym niż kastylijski językiem.

3 Dyskusyjny w tym kontekście może być status Wspólnoty Walencji, gdzie część społeczeństwa podkreśla swoją odmienność językową w stosunku do Katalonii, uznając tym samym, że istnieje odrębny język walencki, a część uważa, że walencki jest tylko pewną odmianą katalońskiego. 
Kwestia tożsamości narodowej, etnicznej czy lokalnej w Hiszpanii jest kluczową sprawą do zrozumienia różnorodności tamtejszego społeczeństwa. Biorąc pod uwagę warunki historyczne, jest państwem, które od początku swojego zinstytucjonalizowania, musiało godzić wielość w ramach jedności. Niekiedy próby takiego jednoczenia przybierały formy, które uderzały w różnorodność kulturowo-językową społeczeństwa tego kraju, a także identyfikacji mieszkańców regionów z państwem. Najtrudniejszy okres przypadł na czas dyktatury frankistowskiej, gdy polityka unifikacji ${ }^{4}$ prowadziła do represji wobec ludności posługującej się językami regionalnymi, kontestującej hiszpański system państwowy oraz ideę unitaryzmu. Polityka okresu frankizmu miała prowadzić do jednolitości całego narodu hiszpańskiego, bez względu na różnice etniczne, kulturowe czy językowe [Biernacka 2016: 51 i nast.].

Po 1975 r. Hiszpania przeszła proces liberalizacji życia politycznego i zmian w kierunku demokracji. Król Juan Carlos w momencie obejmowania władzy po śmierci generała Francisco Franco dostrzegał już, że nowa formuła państwa jest konieczna. Debata na temat przyszłości kraju ukazała, jak głęboko społeczeństwo hiszpańskie jest podzielone pod względem nie tylko poglądów politycznych, ale również pod względem kulturowo-językowym. Kwestia tożsamości regionalnych stała się wkrótce problemem, który mógł zaburzyć dotychczasowe struktury państwa. Dlatego król wraz z rządem Adolfo Suareza zdecydował się na reformę terytorialną, która miała dokonać nie tylko nowego podziału kraju na jednostki terytorialne, ale także scedować dużą część kompetencji na rzecz społeczności zamieszkujących określone regiony. Taki ustrój miał zapewnić partycypację wszystkich obywateli w życiu publicznym Hiszpanii z poszanowaniem różnorodności kultur i języków, a jednocześnie nie doprowadzać do eskalacji żądań przedstawicieli regionów separatyzujących, którzy w trakcie debaty nad reformą państwa, dali wyraz swoim poglądom [Patek, Rydel, Węc 2005: 196-197].

Reforma terytorialna państwa spowodowała, że regiony uzyskały kompetencje w dziedzinie polityki wewnętrznej oraz medialnej. Od 1979 r. do 1983 r. ukonstytuowało się 17 wspólnot autonomicznych (w 1995 r. jeszcze dwa miasta autonomiczne - Ceuta i Melilla), które pod względem prawnym zostały wyposażone w szereg kluczowych procesów decyzyjnych, dotyczących funkcjonowania regionu. Poza kompetencjami wspólnot po-

4 Gen. Francisco Franco za czasów swoich rządów lansował hasło España una, grande y libre! (tłum. Hiszpania jedna, wielka i wolna!) i mimo, że był z pochodzenia Galicyjczykiem, nie podkreślał różnorodności kulturowej społeczeństwa hiszpańskiego. 
została polityka monetarna, zagraniczna i obronna, ale już odpowiednie zapisy w statutach autonomicznych, dotyczące polityki fiskalnej, pozwalały na pozostawienie dużej części podatków w regionie. Rządy poszczególnych wspólnot mogły więc zacząć samodzielnie zarządzać wieloma sferami życia społecznego i gospodarczego, ze sferą komunikacji włącznie.

Z punktu widzenia odradzających się tożsamości regionalnych sfera komunikacji wydawała się być kluczowa, ze względu na kilkadziesiąt lat dyktatury frankistowskiej, która uniemożliwiała rozwój lokalnych języków, kultur i w ogóle identyfikacji innej aniżeli hiszpańskiej. Rządy regionów historycznych, z wyróżniającą się potrzebą samodefiniowania, jako pierwsze zaczęły w sposób systemowy prowadzić działania mające zapewnić rozwój rodzimej kultury oraz tożsamości regionalnej. Polityka medialna wspólnot autonomicznych została zapoczątkowana w latach 80 . XX w. przez utworzenie publicznych nadawców radiowo-telewizyjnych w celu propagowania przede wszystkim języka i kultury regionalnej. Jednak dopiero z końcem lat dziewięćdziesiątych rządy autonomiczne zaczęły regulować te kwestie w sposób bardziej szczegółowy, kładąc szczególny nacisk na misję szerzenia języka i dziedzictwa kulturalnego.

\section{Różnorodność kulturowa wspólnot autonomicznych}

Różnorodność regionalna Hiszpanii wynika z uwarunkowań historyczno-politycznych, które są konsekwencją podziałów politycznych na Półwyspie Iberyjskim. Politykę zjednoczeniową na szeroką skalę zaczęli prowadzić Ferdynand Aragoński oraz Izabela Kastylijska. Właściwie od ich panowania datuje się powstanie instytucji państwa hiszpańskiego. Wcześniej na Półwyspie panowało ogromne rozdrobnienie i brakowało wspólnej koncepcji dla mniejszych jednostek geopolitycznych. Niektórzy historycy zajmujący się dziejami regionów, jak Pedro Esarte Muniain, Tomas Urzainki czy Juan María Olaizaola, uznają jednak politykę konkwisty królów katolickich za okupację rdzennie baskijskich ziem, która doprowadziła do upadku Królestwa Nawarry jako samodzielnego organizmu państwowego, a uznawanego przez baskijskie środowiska nacjonalistyczne za kolebkę państwowości baskijskiej [Esarte Muniain 2001: 53-60; por. Urzainki, Olaizaola: 2000].

Należy więc zauważyć, że koncepcja narodu w przypadku Hiszpanii nie jest jasna, jak przyjmuje się w klasycznych definicjach, uzasadniających, że naród to wspólnota doświadczeń historycznych, kulturowych, o podłożu językowym, terytorialnym, ekonomicznym oraz etnicznym 
[Pietraś 1992: 43]. Przede wszystkim doświadczenia regionów wchodzących w skład współczesnej Hiszpanii są odmienne. Niejednokrotnie znajdowały się one pod panowaniem innych organizacji państwowych (wpływy celtyckie i rzymskie w zachodniej części; mauretańskie na południu Półwyspu Iberyjskiego oraz francuskie na wschodzie). Ponadto, różnice kulturowo-językowe powodowały, że należało wprowadzić jedną wspólną odmianę języka hiszpańskiego, opartą na dialekcie kastylijskim, ponieważ funkcjonowanie takich języków, jak kataloński (catalá), baskijski (euskera) czy galicyjski (galego) nie pozwalało na stworzenie wspólnej przestrzeni komunikacyjnej. W tym przypadku ścierają się odmienne koncepcje, mit „dwu Hiszpanii”. Z jednej strony jest to wspólnota wielu narodów, które w dawnych czasach funkcjonowały jako odrębne królestwa i wspólnym mianownikiem będą wspólne doświadczenia historyczne (najazdy); z drugiej strony jest to wspólnota hispanidad, oparta na centralizmie i chrześcijaństwie, eliminującym pluralizm kulturowy [Kieniewicz 2001: 31-32]. Pojęcie tożsamości narodowej w kontekście społeczeństwa hiszpańskiego również kształtuje się na dwu płaszczyznach. Pierwsza to identyfikacja $z$ regionem, najbliższym otoczeniem, tzw. patria chica (mała ojczyzna), w opozycji do innych regionów, posługujących się własną symboliką czy językiem. Dopiero drugi poziom dotyczy identyfikacji z Królestwem Hiszpanii [Kieniewicz 2001: 280]. Przypadek hiszpański należy więc rozpatrywać głównie w kontekście instytucjonalnym, ponieważ to właśnie państwo zapewniało podstawy do tworzenia narodu i wspólnoty w ramach wielości:

Art. 2: Konstytucja opiera się na nierozerwalnej jedności Narodu hiszpańskiego, wspólnej i niepodzielnej ojczyzny wszystkich Hiszpanów, a także uznaje i zapewnia prawo do autonomii stanowiących go narodowości i regionów oraz solidarność między wszystkimi [Konstytucja Królestwa Hiszpanii z 1978 r.].

Nowa formuła państwa, przyjęta w 1978 r., zakładała więc, że różnorodne świadomości narodowe są wobec siebie kompatybilne, a ich związek ma przede wszystkim charakter polityczny. Jednak, jak zauważył Marek Waldenberg, definicje narodu bywają traktowane przez polityków w sposób instrumentalny, potwierdzając status narodowy niektórych grup lub pozbawiając go innych [Waldenberg 2000: 20]. 


\section{Powiązania mediów i polityki w Katalonii i Kraju Basków}

Relacje pomiędzy mediami a światem polityki w Hiszpanii mają bogatą tradycję i odnoszą się nie tylko do okresu dyktatur. Dziennikarstwo w tym rejonie świata rozwijało się jako zawód służebny wobec określonych idei i zadań społeczno-politycznych. Analizując systemy medialne regionów Hiszpanii nie sposób więc pominąć klasyczną typologię Daniela C. Hallina i Paolo Manciniego, którzy uznali cały system mediów Hiszpanii za przykład spolaryzowanego pluralizmu (inaczej śródziemnomorski), [Hallin, Mancini 2007: 89]. Sama koncepcja jest efektem analizy historycznej, zgodnie z którą autorzy ci proponują podział na model demokratycznego korporacjonizmu, który jest charakterystyczny dla Europy Północnej i Środkowej (kraje skandynawskie oraz niemieckojęzyczne), model liberalny, do którego zalicza się kraje obszaru północnoatlantyckiego (USA, Kanada, Wielka Brytania oraz Irlandia) oraz model spolaryzowanego pluralizmu, do którego należą kraje leżące w basenie Morza Śródziemnego (Hiszpania, Portugalia, Włochy, Grecja, Francja). Pierwszy spośród wymienionych tutaj modeli opiera się na polaryzacji ideologicznej mediów, ale sprzężonej z komercjalizacją rynku, w drugim natomiast kładzie się nacisk na urynkowienie mediów [por. Hallin, Mancini 2007]. W modelu trzecim, odnoszącym się do Hiszpanii, media wykazują wysoką polaryzację ideologiczną, a pluralizm opinii przybiera postać pluralizmu zewnętrznego, wobec czego media różnicują się na podstawie perspektyw światopoglądowych, często sprzyjając określonym siłom politycznym.

Współcześnie paralelizm polityczny w większości krajów demokracji liberalnej nie ma już tak zasadniczego znaczenia jak kiedyś. Media nie są finansowane przez określone partie polityczne, choć ich linia programowa może reprezentować poglądy lewicowe, prawicowe lub centrowe. Model europejski w tej kwestii znacząco odbiega od modelu amerykańskiego, gdzie pluralizm opinii ma być realizowany $\mathrm{w}$ ramach jednego medium. Odbiorcy mediów w Hiszpanii są wobec tego przyzwyczajeni do faktu, że media odzwierciedlają opinie jedynie pewnych grup i środowisk, stając się często ich orężem w walce o określoną sprawę. Odbiorcy poszczególnych mediów dzielą się więc według podziałów społeczno-politycznych. Choć historia gazet stricte partyjnych w hiszpańskim systemie medialnym została przerwana w czasie dyktatur, dominuje tutaj ciągle dziennikarstwo zaangażowane.

Kolejną cechą modelu spolaryzowanego pluralizmu jest przenikanie się elit medialnych z elitami politycznymi, dotyczy to w szczególności me- 
diów publicznych. Model zarządzania publiczną radiofonią i telewizją często przybiera charakter partyjny. W przypadku Hiszpanii już od czasów przemiany systemowej praktykowano zasadę, że partia rządząca miała prawo obsadzać najważniejsze stanowiska w telewizji swoimi ludźmi i realizować własną politykę medialną. Rola publicznych mediów w Hiszpanii nie zmieniła się właściwie od dyktatury frankistowskiej, jedynie zmienił się kontekst działania na prodemokratyczny. Podobny model zarządzania mediami publicznymi przeniesiono także na poziom regionu, gdzie regionalne partie od czasów przyznania autonomii miały zazwyczaj największy wpływ na funkcjonowanie mediów i wyznaczanie im odpowiedniej misji społecznej. W Katalonii największą siłą polityczną od wprowadzenia autonomii stała się Konwergencja i Związek (Convergencia i Unió), a w Kraju Basków - Baskijska Partia Nacjonalistyczna (Partido Nacionalista Vasco).

Media regionalne w kontekście hiszpańskim można wyróżnić na podstawie zasięgu (ograniczony do określonego terytorium, choć istnieją dzienniki ponadregionalne, jak katalońska „La Vanguardia” czy „El Periódico de Catalunya"), treści (tematyka związana z problemami regionu, ale poruszająca również kwestie krajowe i zagraniczne, a w swoich mutacjach - sprawy lokalne) oraz użytkowników (odbiorców o określonej orientacji politycznej, do których są adresowane). Połączenie tych trzech kryteriów pozwala wyróżnić regiony periodycznej komunikacji, które charakteryzują się występowaniem pewnych układów przestrzennych o jednorodnych cechach medialnych [Jachimowski 2006: 61].

System medialny Hiszpanii należy zatem analizować na dwóch poziomach ze względu na specyficzną strukturę terytorialną państwa. Na poziomie ogólnokrajowym występuje prywatna prasa, radiofonia i telewizja, a także ogólnoinformacyjne i tematyczne portale internetowe oraz media publiczne w sektorze mediów audiowizualnych. Podobnego podziału ze względu na kryterium własności można dokonać na poziomie większości z siedemnastu regionów, gdzie wykształciły się specyficzne media regionalne, zarówno wśród mediów prywatnych, jak i publicznych. Wspólnoty autonomiczne posiadają więc własną prasę, radio i telewizję o zasięgu regionalnym, prezentującą problemy z perspektywy mieszkańców regionu, a nie całego kraju. W latach 1982-2005 powstało dwunastu publicznych nadawców radiowo-telewizyjnych, finansowanych z budżetów wspólnot [Głuszek-Szafraniec 2014b: 287]. Każdy z nich przystąpił do Federacji Autonomicznych Rozgłośni Radiowych i Telewizyjnych (FORTA), która jest platformą współpracy pomiędzy nadawcami. Obecnie należą do tej organizacji nadawcy z Andaluzji, 
Katalonii, Wspólnoty Madrytu, Galicji, Kraju Basków, Wysp Kanaryjskich, Kastylii-La Manchy, Murcji, Aragonii, Asturii i Balearów ${ }^{5}$. Oprócz wymienionych, funkcjonują również nadawcy niezrzeszeni w FORTA w regionie Estremadury oraz miastach autonomicznych Ceucie i Melilli.

$\mathrm{W}$ procesie tworzenia własnego systemu medialnego przodowały Kraj Basków i Katalonia, które także jako pierwsze uzyskały statuty autonomiczne, gwarantujące im swobodę rozwoju regionu w ramach państwa regionalnego. Należy zaznaczyć, że prasa baskijska i katalońska funkcjonowały od końca XIX w. Najstarszy dziennik kataloński, „La Vanguardia” powstał w $1881 \mathrm{r}$. W Kraju Basków, ale i w pozostałych regionach, prasa ta miała mniej stabilny charakter i większość współcześnie funkcjonujących tytułów prasy codziennej rozpoczęło swoją działalność po 1975 r., kiedy w Hiszpanii zapoczątkowano dynamiczny okres przemian demokratycznych. Jednak cechą charakterystyczną współczesnych regionalnych systemów medialnych w Hiszpanii jest fakt, że prasa regionalna jest chętniej czytana w porównaniu $\mathrm{z}$ dużymi dziennikami ogólnokrajowymi, jak „El País”, „El Mundo”, „ABC” czy „La Razón”. [Głuszek-Szafraniec 2014 a: 278-279]. Tytuły regionalne i lokalne zaspokajają zapotrzebowanie na informacje o aktualnych wydarzeniach, na temat kultury i historii regionu, problemów określonych społeczności czy też praktycznych wiadomości z najbliższego otoczenia na temat funkcjonowania instytucji, urzędów, kin, teatrów.

Dla rozwoju mediów na poziomie regionalnym kluczowym momentem była decentralizacja państwa, która potwierdziła podziały występujące w społeczeństwie hiszpańskim, ale także zagwarantowała, aby te podziały kształtowały się w kierunku różnorodności, aniżeli antagonizowały mieszkańców Półwyspu Iberyjskiego. Taki przynajmniej był pierwotny zamysł króla Juana Carlosa, który wprowadzając reformę terytorialną kraju, miał swoją osobą scalać Hiszpanię. Jednak jak pisze Monika Kornacka: „Cechą charakterystyczną dla tego typu środków masowego przekazu jest to, iż mają one de facto narzuconą rolę promowania i umacniania regionalizmu" [Kornacka 2014: 240].

Idąca za reformą terytorialną państwa decentralizacja systemu telewizyjnego, sprawiła, że został złamany monopol ogólnokrajowego nadawcy publicznego, Radiotelevisión Española (RTVE). Dzięki inicjatywom w Kraju Basków, a niedługo później w Katalonii powstały regionalne rozgłośnie

5 Od 2013 r. nie ma wśród członków publicznego nadawcy regionalnego ze Wspólnoty Walencji, ponieważ tamtejsze media publiczne zostały zamknięte ze względu na kryzys i aferę korupcyjną z udziałem prominentnych polityków regionalnej filii Partii Ludowej. 
radiowo-telewizyjne, wyprzedzając uregulowania prawne na poziomie centralnym. Statut telewizji TVE otwierał wprawdzie drogę do utworzenia tzw. kanału trzeciego, ale brakowało konkretnych rozporządzeń i ustaw, które uprawomocniłyby tego rodzaju posunięcia [Kuś: 2013, 39]. Rządy regionów separatyzujących nie czekały jednak na działania państwa. Luka prawna w systemie została szybko wykorzystana, tym bardziej, że działalność mediów masowych miała spełnić zasadniczą misję w upowszechnianiu jednolitej formy języka regionalnego i kultury regionu.

$\mathrm{Z}$ perspektywy rozwoju mediów masowych i tworzenia się społeczeństwa obywatelskiego to telewizja miała więc najważniejsze znaczenie. Wynikało to $\mathrm{z}$ dwóch istotnych kwestii. Po pierwsze, prasa masowa w Hiszpanii pozostała $\mathrm{w}$ stadium elitarnym ze względu na wysokie wskaźniki analfabetyzmu na przełomie XIX i XX w.; a po drugie, różnorodność języków i dialektów sprzyjała raczej rozwojowi mediów regionalnych, a nie ogólnokrajowych [Hallin, Mancini: 2007].

Po okresie przemiany systemowej również rządy autonomiczne postawiły na rozwój telewizji regionalnych ze względu na szeroki zasięg oddziaływania i możliwość kształtowania za ich pomocą opinii publicznej w regionach. W 1982 r. w Kraju Basków powołano Baskijską Publiczną Rozgłośnię Radiowo-Telewizyjną (Euskal Irrati Telebista), a w Katalonii utworzono rok później Katalońską Korporację Mediów Audiowizualnych (La Corporació Catalana de Mitjans Audiovisuals). Obaj nadawcy zostali zobowiązani do pełnienia publicznej misji wobec społeczności regionalnych, tj. promocji kultury i języka regionu, jego niezależności i odmienności, wsparcia dla praw i wolności obywatelskich, a także popierania budowy społeczeństwa obywatelskiego.

Cechą specyficzną regionalnych systemów medialnych jest, podobnie jak w systemie mediów ogólnokrajowych w Hiszpanii, występowanie wysokiego stopnia paralelizmu politycznego, zarówno w mediach prywatnych, jak i publicznych. Ponieważ media publiczne regionalne są również zarządzane w modelu parlamentarnym, sprzyja to polityzacji publicznych nadawców. Partie rządzące w regionach mają największy wpływ na działanie mediów, przez obsadzanie stanowisk w ciałach zarządzających, ale również wywierają nacisk na nadawców pod względem oferty programowej. Znamiennym przykładem będzie tutaj sytuacja w Kraju Basków, gdzie w publicznej telewizji ETB przez cały okres rządów baskijskich nacjonalistów z PNV (od końca lat siedemdziesiątych XX w. do 2009 r.) przedstawiano prognozę pogody dotyczącą wszystkich ziem historycznie uznawanych za baskijskie (także tych leżących we Francji). Po krótkotrwałym przejęciu władzy przez 
socjalistów (2009-2012), związanych z centralną partią PSOE, natychmiast dotychczasową mapę ziem baskijskich zastąpiono rzeczywistą mapą terytorium wspólnoty autonomicznej Kraju Basków. Po kolejnej zmianie władzy powrócono do wcześniejszej formuły prognozy pogody, podkreślając tym samym, że Baskowie żyją nie tylko na terytorium Kraju Basków w Hiszpanii, ale i poza nią, we Francji [Głuszek-Szafraniec 2014 a: 285].

Zjawisko paralelizmu politycznego odnosi się również do prasy, przede wszystkim codziennej. W regionach separatyzujących, do których zaliczyć można omawianą tutaj Katalonię i Kraj Basków, dzienniki mają wyraźną opcję polityczną. Stopień tych powiązań ze sferą partyjną jest różny, w zależności od regionu. W Katalonii redakcje prowadzą własną politykę programową i wspierają część inicjatyw partii regionalnych o charakterze narodowo-separatystycznym. Dziennik „La Vanguardia” 6, należący do koncernu rodziny Godo, zaliczyć można do kategorii prasy opiniotwórczej prestiżowej o zasięgu ponadregionalnym, który generalnie sprzyja głównej partii regionu CiU. Jego profil można uznać za umiarkowanie liberalny, choć z wyraźną tendencją prokatalońską. Niejednokrotnie dziennik ten wspierał akcje promowania kultury katalońskiej i niepodległości regionu, a od maja 2011 r. rozpoczął wydawanie edycji całkowicie w języku regionalnym (choć o mniejszej poczytności niż wersja hiszpańskojęzyczna, głównie ze względu na zasięg, ponieważ hiszpańskojęzyczną „La Vanguardię” można kupić w praktycznie każdym większym mieście w Hiszpanii).

Drugi tytuł, „El Periódico de Catalunya”, konkurencyjnego wydawcy grupy Zeta, ma profil wyraźnie lewicowy, ale także sprzyja sprawie katalońskiej, choć nie określa się jako nacjonalistyczny. Od 1997 r. ukazuje się także w dwóch wersjach językowych, identycznych pod względem układu szpalt. Trzecim istotnym tytułem na rynku katalońskim jest „El Punt Avui” (nakład 34393 egz., sprzedaż 23659 egz.), dziennik wydawany w języku regionalnym. Na rynku funkcjonuje od 2011 r., ale powstał z dwóch wcześniej ukazujących się periodyków „El Punt” i „Avui”. Jego linia programowa również wspiera niepodległościowe dążenia Katalonii. Wszystkie trzy gazety są inicjatywami prywatnymi, choć oczywiście nie wyczerpują bogactwa różnorodności tytułów ukazujących się na rynku katalońskim. Na-

6 Według Oficina de Justificación de la Difusión średni nakład między lipcem 2014 a czerwcem 2015 wynosił 78647 egz. w wersji hiszpańskiej i 56743 egz. w wersji katalońskiej, a wydanie niedzielne miało 75236 egz. po hiszpańsku i 62706 egz. po katalońsku.

7 Średni nakład w tygodniu to 51393 egz. wersji hiszpańskiej i 34103 egz. wersji katalońskiej, a wydanie niedzielne 49334 egz. po hiszpańsku i 33146 egz. po katalońsku. 
leżą jednak do czołówki dzienników o zasięgu regionalnym, tj. obejmujących całą Katalonię.

W Kraju Basków można wskazać tytuły, które określa się mianem prohiszpańskich, choć są dziennikami regionalnymi, jak „El Diario Vasco” (63 259 egz. nakładu wg OJD) czy „El Correo - El Pueblo Vasco” (91 745 egz. nakładu, z czego w prowincjach baskijskich nakład wynosi 74115 egz.). Ten drugi tytuł ma wyraźnie konserwatywny profil i choć pojawiają się teksty w języku baskijskim, to zdecydowanie opowiada się za jednością państwa hiszpańskiego. Oba tytuły należą do grupy Vocento, wydawcy ogólnokrajowego dziennika „ABC” o prorojalistycznym nastawieniu, od początku swego istnienia. Na baskijskim rynku funkcjonują również periodyki zdecydowanie wspierające opcję separatystyczną. Dziennikiem o stosunkowo umiarkowanej polityce redakcyjnej wśród tej grupy pism jest „Deia” (wg OJD 17582 egz. nakładu), który został założony w 1977 r., czyli w okresie przemian społeczno-politycznych w Hiszpanii. Impuls do jego powstania wyszedł z szeregów Baskijskiej Partii Nacjonalistycznej (PNV), która od początku autonomii była główną siłą polityczną w Kraju Basków. „Deia” ma wyraźny profil probaskijski, choć w przypadku sceny baskijskiej jest jednym z bardziej umiarkowanych mediów tej opcji. Jego polityka redakcyjna jest dostosowana do aktualnej sytuacji partii PNV, która miewała w swojej historii zarówno centrowe programy, jak i radykalizowała się w okresach, gdy obóz separatystów rósł w siłę.

Opcję wyraźnie separatystyczną przyjmowały dzienniki, które obecnie nie funkcjonują na baskijskim rynku prasowym. Pierwszym dziennikiem, związanym z lewicą radykalną abertzale był „Egin”, który istniał w latach 1977-1998 [por. Caminos-Marcet, Armentia-Vizuete, Marín-Murillo 2013: 1-26]. „Egin” przedstawiał poglądy tak radykalne, że zostały uznane za niemieszczące się w ramach demokratycznego porządku i wolności słowa. W 1998 r. sędzia Baltasar Garzón zdecydował o zamknięciu redakcji i mediów z nią powiązanych [Głuszek 2004: 98]. Czytelników „Egin” przejęła założona w 1990 r. gazeta „Euskaldunak Egunkaria”, która była wydawana całkowicie w języku baskijskim i równie radykalna jak „Egin”. W 2003 r. podzieliła los dziennika „Egin” ze względu na oskarżenia o powiązania z organizacją terrorystyczną ETA. Po licznych protestach społecznych w Kraju Basków w obronie wolności słowa i mediów, założono kolejny dziennik

8 Na przykład z końcem lat dziewięćdziesiątych XX w., jak i w latach 2002-2005, kiedy PNV występowała z planem „swobodnego stowarzyszenia” z Hiszpanią, znanego jako plan Ibarretxe. 
„Berria”". Jest on redagowany również w języku baskijskim i kontynuuje linię programową „Egin” oraz „Euskaldunak Egunkaria”. W nurcie radykalnego nacjonalizmu mieści się także dziennik „Gara” (25 tys. egz. $\left.{ }^{10}\right)$, który uznawany jest za bezpośredniego spadkobiercę dziennika „Egin”. „Gara” powstał tuż po zamknięciu gazety „Egin”, a ufundowano go ze środków zebranych od obywateli baskijskich w ramach Stowarzyszenia Mediów Baskijskich (Euskal Komunikabideen Hedapenerako Elkartea), które do dziś jest właścicielem dziennika i kilku innych mediów, m.in. „Zazpika” (magazyn niedzielny do dziennika "Gara”), "Gaur8” (tygodnik baskijskojęzyczny), Info 7 (radio w języku baskijskim) oraz „Mediabask” (francuskojęzyczny regionalny portal ogólnoinformacyjny). Codzienna prasa baskijskojęzyczna jest reprezentowana $\mathrm{w}$ mniejszym stopniu na poziomie regionu aniżeli dzienniki w Katalonii, a jej odbiór w porównaniu z regionalną prasą hiszpańskojęzyczną jest słabszy.

\section{Polityka medialna władz Wspólnoty Autonomicznej Katalonii}

Jako wzorzec polityki tożsamościowej posłużyć może polityka medialna Katalonii, która jest najbardziej zaawansowana pod względem autonomizacji systemu medialnego regionu w stosunku do mediów hiszpańskojęzycznych. Zaznaczyć należy, że działania te wzmacniają używanie języka katalońskiego w sferze publicznej w celu rozpowszechnienia go wśród mieszkańców Katalonii. Pierwsze przepisy prawne dotyczące działalności środków masowego komunikowania zostały uchwalone w Katalonii w 1983 r., ale współcześnie podstawą działalności mediów katalońskojęzycznych jest ustawa o polityce językowej z 1998 r. (La Ley 1/1998 de política lingüística), a konkretnie rozdział IV ustawy zatytułowany „Media masowe i przemysły kulturalne”. Przepisy regulują tutaj przede wszystkim działalność publicznego radia i telewizji, które powinny promować wydarzenia związane z kulturą katalońską oraz język regionalny, w tym język

9 Nakłady dzienników „Berria” i „Gara” oraz tygodników nie są kontrolowane przez OJD. Dane z 2014 roku na temat czytelnictwa prasy w Kraju Basków wskazywały, że średnio jeden numer „El Correo” ma 447 tys. czytelników, „El Diario Vasco” 249 tys., „Deia” 94 tys., „Gara” 81 tys., a „Berria” 48 tys. czytelników. Oznaczałoby to, że z jednym wydaniem gazety zapoznaje się potencjalnie 3-4 czytelników. Dane za CIES Estudios de Mercado y Opinión, http://www.ciessl. com/imagenes/13.pdf (02.03.2016).

10 Informacja otrzymana przez autorkę z redakcji dziennika „Gara”. Dane te dotyczą średniego dziennego nakładu w pierwszym kwartale $2016 \mathrm{r}$. 
arański dla mieszkańców Doliny Aran. Ponadto, rząd Katalonii ma ułatwiać mieszkańcom dostęp do innych telewizji, które emitują programy w języku katalońskim (art. 25).

Kolejna kwestia dotyczy produkcji katalońskojęzycznych. Nadawcy koncesjonowani powinni na antenie emitować minimum 50\% tego typu programów. Podobna sytuacja dotyczy rozgłośni radiowych, ale tutaj udział audycji w języku regionalnym może być regulowany w zależności od konkretnego przypadku. Uzależnia się także przyznanie koncesji nadawcom naziemnym, czy kablowym, jak również radiowym w zależności od oferty programowej w języku regionalnym. Ponadto, rozgłośnie radiowe powinny emitować utwory artystów katalońskich w języku regionalnym (także arańskim), (art. 26; minimum 25\%). W przypadku mediów drukowanych, wydawanych przez jednostki administracji publicznej na terenie Katalonii, również wymaga się używania języka regionalnego. Wymóg ten dotyczy także innych lokalnych przedsięwzięć. Według ustawy, rząd kataloński może udzielać subwencji zarówno prasie codziennej, jak i periodycznej, drukowanej w całości lub w większości w języku regionalnym [por. Głuszek-Szafraniec 2014 c : 87]. Kryterium przyznawania subwencji jest zasięg, komercjalizacja oraz używanie języka katalońskiego. Rozdział środków finansowych jest kontrolowany przez lokalny parlament (art. 27). Rząd kataloński zobowiązał się również do wspierania i promowania kultury i sztuki katalońskiej w różnych formach, tj. literatury, teatru, publikacji, wydarzeń kulturalnych oraz kinematografii, do której odnosi się również osobna ustawa o kinie z 2010 r., zobowiązująca dystrybutorów filmów do dostarczania kopii filmu również z tłumaczeniem katalońskim. Wprowadzenie tej ustawy było związane z faktem, że Katalończycy, choć używali języka regionalnego na co dzień, nie mieli możliwości zapoznawania się z kulturą popularną w tym języku [por. Głuszek-Szafraniec 2014 a, 240]. Wiele nowości kinowych ma być więc, według ustawy, dubbingowanych na kataloński lub wyświetlanych z napisami. W 2015 r. subwencje w wysokości 97 tys. euro zostały przyznane na dubbing do filmu Star Wars: Przebudzenie mocy. Film w wersji katalońskojęzycznej trafił do 30 kin, ale okazało się, że zabrakło odpowiedniej promocji, by oferta ta stała się popularna. Sagę wyświetlano w mniejszych salach, bez wersji 3D, nie do wszystkich kin dostarczono także trailer filmu w języku katalońskim. Jak się więc okazuje, środki przeznaczane na dofinansowanie oferty medialnej w języku regionalnym nie zawsze są wykorzystywane w sposób adekwatny do przyjętego założenia. $\mathrm{W}$ tym przypadku pojawiło się wiele głosów kry- 
tycznych na temat braku odpowiedniej promocji filmu, by widzowie zainteresowani wersją katalońską mogli ten film obejrzeć [Alós 2015].

Przypadek kataloński mimo to można uznać za wzorcowy, ponieważ ustawowo wspiera się także nowe technologie (art. 29 ustawy o polityce językowej z 1998 r.), które swoim użytkownikom umożliwiają korzystanie z różnych aplikacji, gier komputerowych, oprogramowań w języku katalońskim. W ten sposób zapewnia się dynamiczny rozwój języka wraz z zapotrzebowaniami jego użytkowników i zmieniającą się rzeczywistością. W przeciwnym wypadku Katalończycy musieliby korzystać z terminologii funkcjonującej już w języku hiszpańskim. Ta sama ustawa o polityce językowej odniosła się także do kwestii języka regionalnego w biznesie, wymagając od producentów używania w dokumentach handlowych na terenie Katalonii języka miejscowego, jak również umieszczania etykiet informacyjnych na produktach w tym języku (art. 34), [por. Głuszek-Szafraniec 2014 c: 88].

Warto zaznaczyć, że ważną rolę w kształtowaniu oferty mediów odgrywa wspomniany system subwencji. Media w Katalonii otrzymują od rządu autonomicznego wsparcie finansowe na rozbudowę oferty w języku katalońskim. Dotyczy to zarówno segmentu prasy, zwłaszcza bezpłatnej, jak i prywatnych nadawców radiowych, którzy będą emitowali muzykę katalońską i utwory współczesnych artystów katalońskich, jak i mediów internetowych oraz innych przedsięwzięć promujących język i kulturę regionalną [por. GłuszekSzafraniec 2014 a: 237]. System ten zaczął działać na większą skalę w 2008 r. Do 2014 r. rząd kataloński wydał na ten cel $82 \mathrm{mln}$ euro, wpierając w ten sposób bezpośrednio ok. 600 różnych mediów, które publikowały materiały w języku regionalnym, a często także lansowały ideę niepodległości Katalonii. Dodatkowo, formą pośrednią subwencji są ogłoszenia administracji publicznej, publikowane w mediach. Na ten cel w latach 2008-2014 wydano aż 99 mln euro, dając w ten sposób możliwość finansowania swojej działalności mediom katalońskim. Uważa się jednak, że system podziału ogłoszeń rządowych miał charakter uznaniowy [Rubió 2014].

Polityka budowania tożsamości katalońskiej przez popularyzację języka jako głównego wyznacznika oraz symbolu kultury i społeczeństwa katalońskiego ${ }^{11}$ była monitorowana w szerokich badaniach ankietowych dotyczących praktyk językowych i kulturalnych w Katalonii. Seria tych badań

11 Należy zaznaczyć, że język kataloński jest używany nie tylko we wspólnocie autonomicznej Katalonii, ale również w Walencji i na Balearach. Na początku 2016 r. parlament wysp na Morzu Śródziemnym wprowadził modyfikację do polityki językowej w przestrzeni publicznej. Nowelizacja wprowadza zmianę w kierunku popierania języka katalońskiego, ponieważ jest to prawo 
została przeprowadzona przez Instytut Statystyki Katalonii (1985, 1991, 1996, 2001 i 2006). W dwóch obszernych publikacjach z 2001 i 2006 r. można zapoznać się z wynikami badań nad społeczeństwem katalońskim.

W 2001 r. 76,7\% ludności Katalonii (3 985,5 mln z 5 197,6 mln mieszkańców w tamtym czasie) czytało prasę codzienną. Największą popularnością cieszyły się dzienniki ogólnoinformacyjne (69,4\% czytelników prasy codziennej) $)^{12}$, a następnie prasa lokalna $(14,7 \%)$ oraz sportowa $(12,5 \%)$. Tematem, który najbardziej interesował badanych czytelników, była polityka wewnętrzna $(24 \%)^{13}$ i polityka zagraniczna (13,8\%). Czasopisma czytywało ok. 51\% ludności (2 197,6 mln spośród 5 197,6 mln mieszkańców), a do kina chodziło 63\% ogółu ludności. Jednak tylko 4,3\% uczęszczających do kina (spośród 3274,3 mln widzów) oglądało filmy po katalońsku, a 90,8\% po hiszpańsku (a także w niewielkim odsetku w innych językach). W 2001 roku oglądano średnio telewizję 2,5 godziny dziennie, a radia słuchano 2,7 godziny (w weekendy mniej, bo 1,3 godziny). Najczęściej oglądaną telewizją była publiczna katalońska TV3 $(31,1 \%)^{14}$, a następnie kanały komercyjne ogólnokrajowe Tele $5(18,8 \%)$ oraz Antena 3 (15\%). Publiczną telewizję hiszpańską TVE oglądało w Katalonii 12,2\% widzów. 24,7\% badanych oglądało telewizję głównie po katalońsku ${ }^{15}$, a 36,5\% badanych osób wybierało ofertę w języku regionalnym $\mathrm{w}$ połowie czasu przeznaczanego na tego rodzaju rozrywkę. Najpopularniejszym nadawcą radiowym w $2001 \mathrm{r}$. była publiczna regionalna rozgłośnia Catalunya Radio, finansowana z budżetu autonomii. Słuchało jej 18,8\% ${ }^{16}$ odbiorców. Na kolejnych pozycjach znaleźli się nadawcy prywatni i lokalni, natomiast publiczne radio hiszpańskie RNE1 dopiero na szóstej pozycji (5,2\%). Radia słuchano głównie po katalońsku (40,2\% badanych) $)^{17}$, [por. Enquesta de consum... 2001, 2003: 164-165].

mieszkańców Balearów, którzy należą do tej samej grupy językowej, a wiele toponimów nazw miejscowych pochodzi z katalońskiego.

W przypadku wyboru rodzajów prasy możliwe były dwie odpowiedzi.

13 W przypadku tematyki możliwe było wybranie trzech odpowiedzi.

14 Możliwy był wybór trzech odpowiedzi spośród podanej oferty.

15 Ponad 90\% oglądanej oferty programowej była po katalońsku. Badaniom poddano 3573,4 mln osób w Katalonii.

16 Można było wybrać trzy odpowiedzi.

17 Ponad 90\% słuchanej oferty programowej była po katalońsku. Przebadano wówczas 2 635,7 mln słuchaczy. 
Rok 2006 pokazał w społeczeństwie katalońskim dość niespotykane tendencje na rynku czytelniczym. Wzrosła liczba ludności czytającej prasę codzienną (89,7\% populacji powyżej 15 roku życia, co stanowiło w tamtym czasie 5 385,4 mln osób spośród 6 003,5 mln mieszkańców). Zyskała przede wszystkim prasa lokalna $(26,6 \%)$ i sportowa $(17,2 \%)$ kosztem dzienników ogólnoinformacyjnych (56\%). Należy pamiętać, że rok 2006 był szczególny z perspektywy rozwoju autonomii katalońskiej, ponieważ 18 czerwca 2006 r. przyjęto nowy statut autonomiczny, który wprowadził pojęcie narodowości katalońskiej oraz wiele dodatkowych przywilejów, np. wzmacniających status języka katalońskiego, dyskryminując przy tym hiszpański $\mathrm{w}$ przestrzeni publicznej oraz w systemie edukacji [por. Głuszek-Szafraniec 2011: 180-183]. Jednak oferta największego dziennika katalońskiego „La Vanguardia” tylko częściowo była dostępna w języku regionalnym. Swoją wersję w pełni katalońskojęzyczną uruchomił dopiero w 2011 roku. Dzienniki „Avui” (później „El Punt Avui”) oraz „El Periódico de Catalunya” były dostępne w badanym okresie po katalońsku, jak również liczne tytuły prasy lokalnej, o mniejszym zasięgu. Nastąpił także wzrost liczby czytelników czasopism (74,2\%). Spadł natomiast odsetek widzów w kinach $(55,6 \%)^{18}$. Wzrósł jednak odsetek osób oglądających filmy w języku katalońskim (do 10,6\%) w porównaniu z ofertą hiszpańskojęzyczną $(83,5 \%)^{19}$, [por. Enquesta de consum i pràctiques culturals 2006, 2008].

W 2008 r. rynkiem mediów w Hiszpanii (i nie tylko) wstrząsnął kryzys. System subwencji miał wspomóc prasę regionalną, która nie zawsze była w stanie przetrwać trudny czas na rynku komercyjnym, spełniając jeszcze określone zadania wobec społeczeństwa. W Katalonii system subsydiów dla mediów istnieje już od lat osiemdziesiątych XX w., co plasuje ten region w czołówce autonomicznych systemów medialnych [Por. Fernández Alonso, Blasco Gil, 2014]. Katalonia jest także najbardziej wyemancypowaną wspólnotą, której dążenia do separacji przybierają coraz bardziej realny kształt. Zaangażowanie rządu katalońskiego w budowę systemu mediów katalońskojęzycznych oraz wprowadzenie różnego rodzaju programów pomocowych dla tytułów i przedsięwzięć (obecnie głównie w Internecie), mających na celu popularyzację języka regionalnego i propagowanie dziedzictwa kulturalnego Katalonii może być cechą wskazującą na przynależność modelu systemu medialnego do kategorii demokratycznego korporacjonizmu, gdzie według

18 Wszystkie dane procentowe w 2006 r. dotyczą całkowitej populacji 6.003,5 mln Katalonii.

19 Dane te dotyczą $4109 \mathrm{mln}$ badanych widzów. 
Hallina i Manciniego media mają do spełnienia określoną rolę wobec społeczeństwa, a państwo winne jest wspierać różnego rodzaju inicjatywy, aby oddać pełen pluralizm opinii. Rynek medialny nie opiera się jedynie na zasadach komercjalizacji, ponieważ media pojmowane są jako swego rodzaju dobro publiczne. Wydaje się więc, że system mediów regionalnych w Katalonii ma charakter hybrydalny, tj. obok stricte komercyjnych działają media, które mają przede wszystkim jakiś cel i reprezentują poglądy określonych grup lub części społeczeństwa, nie kierując się jedynie zasadą zysku.

\section{Polityka medialna we Wspólnocie Autonomicznej Kraju Basków}

Pierwsze regulacje dotyczące normalizacji językowej w Kraju Basków pojawiły się w 1982 roku (Ley 10/1982, Básica de normalización del uso del Euskera, ustawa o normalizacji używania języka baskijskiego). Dotyczyły one zbudowania tożsamości baskijskiej, który to proces należałoby w polskiej wersji nazywać pojęciem baskonizacji (reeuskaldunización od słowa w języku euskera 'euskaldun' - Bask) mieszkańców Wspólnoty Autonomicznej Euskadi (Comunidad Autónoma de Euskadi, CAE - czyli Kraju Basków), którzy na nowo mieli uczyć się języka baskijskiego i używać go na co dzień. Już wtedy poświęcono mediom w języku baskijskim cały rozdział III ustawy, w której rząd baskijski zobowiązał się do promocji i ochrony języka regionalnego w prasie, radiu, teatrze, kinie i innych przedsięwzięciach kulturalnych, a także zastrzegł, że będzie motywował nadawcę publicznego RTVE do zamieszczania oferty w języku euskera (art. 24). Ustawa ta nie mówiła jeszcze o własnej telewizji, która stała się później sztandarowym medium (od końca 1982 r.), wspierającym rząd autonomiczny w odbudowywaniu tożsamości regionalnej mieszkańców Kraju Basków. Podobnie jak w Katalonii, również w Kraju Basków kontynuowano regularną politykę językową, która miała na celu promocję języka regionalnego. W 1998 r. uchwalono Plan Generalny Promocji Używania Języka Baskijskiego, który zakładał podjęcie współpracy także pomiędzy podmiotami prywatnymi. Natomiast w 2013 r. uchwalono Plan Działań dla Promocji Języka Baskijskiego. Główny ciężar promocji języka nadal spoczywa, według niniejszego planu, na regionalnym nadawcy publicznym EITB. Plan zakłada również współpracę między mediami sektora publicznego i prywatnego oraz podtrzymuje system subwencji dla tych mediów, które będą w swojej ofercie zamieszczały materiały w języku regionalnym. Rząd baskijski założył, że wsparcie finansowe ma służyć skonstruowaniu baskijskiego systemu medialnego, z reprezentacją mediów w każdym 
segmencie, adresowanych do różnorodnych kategorii społeczeństwa. W planie zapisano, że należy wspierać rozwój mediów baskijskojęzycznych w celu zwiększenia liczby obywateli, którzy tym językiem potrafią się posługiwać [Plan de Acción para... 2013: 77-79].

W Kraju Basków, podobnie jak w Katalonii, uruchomiono system subwencji dla mediów, które zdecydują się promować język regionalny w przestrzeni publicznej. Skala tych subwencji jest jednak znacznie mniejsza aniżeli w przypadku Katalonii. W latach 2008-2014 wydano na ten cel 21 mln euro [Rubió 2014]. Działa on jednak w podobny sposób jak w Katalonii. Ogłasza się więc różnorodne konkursy i granty, które mogłyby wspomóc media w tej działalności. Ponieważ prasa regionalna w Kraju Basków jest w większości przypadków dwujęzyczna (jedynym dziennikiem całkowicie w języku euskera jest powstały w 2003 r. „Berria”; baskijskojęzyczne tygodniki oraz prasa lokalna o mniejszym zasięgu jednak funkcjonują), kładzie się nacisk na promocję języka w Internecie. Jeden z ostatnich konkursów na 2016 r. został skierowany do prasy codziennej, która w wersji papierowej w Kraju Basków ukazuje się przede wszystkim w języku hiszpańskim, oraz do agencji informacyjnych. Proponuje się, aby wydawcy gazet oraz agencje na swoich portalach zaczęły częściej publikować informacje w języku regionalnym. Na program ten przeznaczono w sumie w 2016 r. 400 tys. euro, z czego 350 tys. euro skierowano do internetowych wydań prasy codziennej, a 50 tys. euro do agencji informacyjnych [Boletín Oficial del País Vasco, 2015]. Rząd baskijski chciałby w ten sposób zapewnić stałą obecność języka w mediach, a przez to spopularyzować jego używanie w sytuacjach codziennych. Założenia strategii dla rozwoju języka baskijskiego na lata 2013-2016 przewidują także promocję domeny .eus w Internecie oraz rozwój baskijskojęzycznej Wikipedii czy tworzenie różnych wersji aplikacji w języku regionalnym [por. Agenda Estratégica del Euskera 2013-2016].

Działania rządu baskijskiego mają uzasadnienie w danych statystycznych dotyczących odbioru mediów baskijskojęzycznych. Najnowsze wyniki badań pochodzą z 2011 r. [por. Medios de comunicación 2012]. Okazuje się, że najczęściej oglądanym kanałem w Kraju Basków jest ciągle TVE1 (19\%), na drugim miejscu znajduje się prywatny Tele 5 (14\%), a dopiero na trzecim ETB2 (12\%), kanał publicznej telewizji autonomicznej, ale po hiszpańsku. Kanał ETB1, który emituje programy wyłącznie po baskijsku jest na ósmej pozycji (6\%). Wyprzedzają go kanały komercyjne i drugi program publiczny TVE. Kanał ETB1 zebrał jednak sporo negatywnych opinii dotyczących jakości emitowanych programów (13\%; na drugim miejscu po Tele 5, które uzyskało aż 38\% 
negatywnych opinii, ale kanał ten należy do koncernu Silvio Berlusconiego i jego jakość jest porównywalna $\mathrm{z}$ włoską ofertą magnata medialnego).

Dane dotyczące prasy wskazują, że w dziennikach najczęściej czytaną rubryką jest ta dotycząca Kraju Basków (aż 43\%), później informacji lokalnych (40\%), sportu (27\%) i dopiero Hiszpanii jako całości (14\%). Spośród dzienników, najczęściej czytanymi tytułami są hiszpańskojęzyczne „El Correo - El Pueblo Vasco” i „El Diario Vasco” (w sumie 77\%), następnie „Diario Noticias” (11\%) i „Deia” (11\%) oraz „Gara” (9\%). Dziennik „Berria”, całkowicie w języku baskijskim zyskuje 5\% czytelników. Dwutygodnik „Hitza”, także periodyk w języku regionalnym, ma 2\% czytelników. Radio autonomiczne $\mathrm{w}$ języku regionalnym jest natomiast najczęściej słuchanym nadawcą (31\%) (Radio Euskadi/Euskadi Irratia/Radio Vitoria). Na drugim miejscu znalazła się komercyjna sieć SER, należąca do koncernu PRISA. Także w czołówce znalazło się publiczne radio dla młodzieży Gaztea (12\%), które ma charakter muzyczny, ale emituje programy w języku baskijskim.

System medialny Kraju Basków jest w porównaniu z systemem katalońskim znacznie mniej rozbudowany. Oferta mediów regionalnych w języku rodzimym jest uboższa. Częściej podejmuje się inicjatywy lokalne, ale mają one często efemeryczny charakter. Wydaje się więc, że konsolidacja rynku medialnego może być tutaj istotna w konstruowaniu poczucia odrębności wśród mieszkańców regionu. Mimo iż oferta lokalna (choć nie omówiona w niniejszym tekście) jest w Kraju Basków różnorodna, to nie pełni na tyle integracyjnej funkcji, by odgrywać ważną rolę w polityce baskonizacji społeczeństwa na poziomie całego regionu.

\section{Status języków regionalnych we wspólnotach autonomicznych w XXI wieku}

Język regionalny oraz jego znajomość wśród mieszkańców Wspólnot Autonomicznych jest kluczową kwestią w prowadzeniu polityki tożsamościowej rządów Katalonii i Kraju Basków. W obu Wspólnotach prowadzone są więc cykliczne badania na temat używania języków regionalnych. Statystyki te mają służyć sprawdzeniu efektywności podjętych działań i programów. W kontekście rozwoju mediów regionalnych język jest nie tylko przedmiotem polityki tożsamościowej, ale i jej instrumentem.

W Kraju Basków ostatnie szerokie badania na temat języka baskijskiego przeprowadzono w 2011 r. Ankieta dotyczyła sytuacji socjolingwistycznej w różnych częściach Baskonii, rozumianej jako wszystkie ziemie hi- 
storycznie związane z kulturą baskijską, tj. we francuskim Kraju Basków, Wspólnocie Autonomicznej Kraju Basków oraz w części Nawarry. Ponieważ formalna polityka rządu regionalnego obejmuje terytorium Wspólnoty Autonomicznej Kraju Basków, należy się skupić na statystykach dotyczących właśnie tej części. Szacuje się, że na wszystkich ziemiach baskijskojęzycznych w euskera mówi 27\% mieszkańców, a 14,7\% rozumie ten język; 58,3\% nie mówi w ogóle po baskijsku. W Kraju Basków, który składa się z trzech prowincji: Gipuzkoi, Bizkai oraz Alavy, dwujęzyczna ludność stanowi 32\% ogółu, natomiast dwujęzycznych pasywnych osób (rozumiejących baskijski, ale mówiących głównie po hiszpańsku) jest 17,4\%. Ci, którzy w ogóle nie porozumiewają się po baskijsku, stanowią 50,6\% mieszkańców Kraju Basków. Najwyższe wskaźniki euskaldunizacji ma prowincja Gipuzkoa, bo aż 33,7\% zamieszkałej tam ludności porozumiewa się w obu językach. Najniższe prowincja Alava, gdzie tylko 16,8\% ludności posiada kompetencje językowe pozwalające na używanie języka hiszpańskiego i baskijskiego w tym samym stopniu [V Encuesta Sociolingüistica 2013].

Aby sprawdzić, czy polityka rządu regionalnego Kraju Basków przynosi zamierzone efekty, warto porównać wskaźniki osób mówiących w języku regionalnym sprzed lat. W 1991 r. odsetek osób mówiących w euskera i hiszpańskim jednocześnie na terytorium wspólnoty autonomicznej Kraju Basków wynosił 24,07\%. Pasywnych użytkowników w tym czasie było 8,54\%, a osób w ogóle nie rozumiejących baskijskiego aż 67,39\%. Na wszystkich historycznych ziemiach baskijskich (czyli w Kraju Basków, Baskonii francuskiej i w północnej Nawarze) z początkiem lat dziewięćdziesiątych XX w. w dwu językach ${ }^{20}$ porozumiewało się $22,29 \%$ osób, a pasywnych użytkowników było 7,71\%, jednojęzycznych natomiast aż 70\% [por. eustat.eus]. W 2001 r. odsetek osób dwujęzycznych zwiększył się o 5\% (do 29,39\%) we Wspólnocie Autonomicznej, a w całej Baskonii o 3\% (do 25,39\%). Przybył również odsetek mieszkańców, którzy rozumieli już język baskijski, choć nie mówili nim biegle: w Kraju Basków do 11,41\%, a w całej historycznej Baskonii do 10,55\%. Wskaźniki te pokazują więc, że nowe pokolenie Basków dzięki polityce rządu regionalnego, sprzyjającej obecności języka regionalnego w różnych sferach życia publicznego, zaczyna mówić i rozumieć euskera. Co ważne, w 2011 r. odsetek młodych Basków (między 16 a 24 rokiem życia) władających biegle zarówno hiszpańskim, jak i rodzimym języ-

20 Dotyczy to sytuacji, gdy ludność porozumiewa się zarówno w języku hiszpańskim i baskijskim, jak i francuskim i baskijskim. 
kiem wynosił już 59,73\%. Jednak mimo, iż znajomość języka baskijskiego wśród młodzieży jest coraz powszechniejsza, okazuje się, że ciągle niewielu Basków posługuje się nim jako głównym językiem w swoich domach (13,4\%). Aż 77,1\% mówi w domu wciąż po hiszpańsku, a mieszaniną hiszpańskiego i baskijskiego 7,4\% [Más vascos saben euskara... 2014].

Badania na temat języka katalońskiego również były przeprowadzane cyklicznie co kilka lat [Informe de política lingüística 2013], ale ponieważ do Katalonii przybywa wysoki odsetek imigrantów z innych części świata hispanojęzycznego, jak również z Afryki Północnej, wyodrębniono więcej szczegółowych kategorii aniżeli w badaniach socjolingwistycznych w Kraju Basków. W 2013 r. dla 31\% Katalończyków powyżej 15 roku życia językiem początkowym był kataloński, a dla 55,1\% był to hiszpański. 36,4\% mieszkańców Katalonii identyfikuje się z językiem katalońskim, a dla 36,3\% jest to język zwykle używany w sytuacjach życia codziennego. Mieszkańcy hiszpańskojęzyczni stanowią ok. 50\% społeczeństwa Katalonii. W latach 2008 i 2013, kiedy przeprowadzano najnowsze badania, zauważono tendencję, że wzrasta odsetek użytkowników katalońskiego na co dzień w porównaniu z odsetkiem osób, dla których hiszpański był pierwszym językiem (tj. w którym zaczynano w ogóle mówić w wieku dziecięcym).

Sytuacja socjolingwistyczna w Katalonii wydaje się więc być stabilna, pomimo napływu ludności z zagranicy, głównie krajów arabskich, Rumunii, Francji, Włoch, Portugalii, Wielkiej Brytanii, ale również hiszpańskiej Galicji. Na 7,5 mln mieszkańców Katalonii w 2013 r. 63,7\% urodziło się w Katalonii, 18,8\% pochodziło z innych części Hiszpanii, a 17,5\% z zagranicy. Z początkiem lat osiemdziesiątych XX w. Katalonię zamieszkiwało tylko 1,5\% cudzoziemców oraz 34,4\% Hiszpanów z innych regionów. Wskaźniki te zaczęły się zmieniać na początku XXI w., kiedy odnotowano duży napływ imigrantów (w 2003 r. w Katalonii mieszkało 9,3\% cudzoziemców). Rząd kataloński zdecydował się więc wprowadzić politykę katalonizacji również ludności napływowej.

Szacuje się, że w drugiej dekadzie XXI wieku nieco ponad 94\% dorosłej części mieszkańców Katalonii (tj. powyżej 15 roku życia) w jakimś stopniu rozumie język regionalny, a 80,4\% potrafi porozmawiać po katalońsku; $82,4 \%$ czyta, a 60,4\% potrafi pisać. Oczywiście sytuacja Katalonii jest o tyle odmienna od Kraju Basków, że w momencie uzyskania autonomii duża część mieszkańców nowo utworzonej wspólnoty autonomicznej rozumiała już język kataloński (w 1981 r. 79,8\%; w 1991 już 93,8\%; w 2001 ten odsetek wynosił 94,5\%, a w 2011 - 95,2\%), choć niekoniecznie swobodnie się nim 
porozumiewała [Informe de política lingüística 2013: 6]. Na specyficzną sytuację socjolingwistyczną Katalonii wpływa na pewno imigracja z krajów Ameryki Łacińskiej, która może nieco podwyższać wskaźnik ludności hiszpańskojęzycznej oraz z krajów arabskich. Wskaźniki ludności katalońskojęzycznej są jednak ciągle ustabilizowane, pomimo zmian demograficznych w ostatnich latach, co oznacza, że zwiększa się de facto odsetek osób posługujących się językiem regionalnym w życiu codziennym.

\section{Wnioski}

Współczesna Hiszpania jest krajem wielu kultur i języków, które funkcjonują obok siebie na zasadach pokojowego współistnienia. Od końca lat siedemdziesiątych XX w., kiedy kraj przeszedł transformację demokratyczną, regiony zaczęły podkreślać swoją podmiotowość dzięki wyposażeniu ich przez władzę centralną w odpowiednie kompetencje prawnopolityczne. Takie regiony jak Kraj Basków i Katalonia skorzystały z przyznanych im narzędzi w celu kształtowania własnej polityki tożsamościowej, polegającej na odbudowaniu lub czasem wręcz skonstruowaniu od podstaw społeczeństwa identyfikującego się z regionem. Poczucie tożsamości regionalnej odgrywa wśród mieszkańców Hiszpanii pierwszoplanową rolę. Umiejętne pokierowanie dostępnymi środkami przez rządy regionalne pozwoliło więc wzmocnić w niektórych wspólnotach ten efekt. Dotyczy to głównie regionów separatyzujących, których społeczeństwa odczuwają wysoki stopień odrębności od pozostałych części państwa regionalnego.

Przypadek Kraju Basków i Katalonii od samego początku nadania statutów autonomicznych tym terytoriom pokazuje, że płaszczyzna komunikacji masowej jest jedną $\mathrm{z}$ kluczowych $\mathrm{w}$ budowaniu społeczeństw regionalnych. Proces ten nie odbywa się we wszystkich regionach w ten sam sposób, ale oba analizowane w niniejszym artykule kazusy wskazują na pewne wspólne rozwiązania, które prowadzą do sukcesu w tej dziedzinie. Po pierwsze, rządy regionalne postawiły na stworzenie odrębnych od systemu medialnego Hiszpanii publicznych środków komunikacji masowej. Były w tej dziedzinie prekursorami spośród wszystkich 17 wspólnot autonomicznych. Uznały, że publiczne radio i telewizja będą tymi mediami, dzięki którym będzie można prowadzić odpowiednią politykę tożsamościową. Po drugie, system edukacji językowej został sprzężony z systemem medialnym w celu budowania przestrzeni publicznej dla dyskursu prowadzonego w języku regionalnym. Po trzecie, budowa systemu komunikacji masowej otrzy- 
mała wsparcie finansowe ze strony budżetu wspólnoty, aby zwiększyć udział użytkowników języka regionalnego wśród mieszkańców wspólnoty, ale także by zapobiec kryzysom związanym z koniunkturą rynkową, która media niekomercyjne, ale z misją społeczną, może doprowadzić do bankructwa.

Zróżnicowanie kulturowe społeczeństwa Hiszpanii powoduje, że realizowane są odrębne polityki kształtowania tożsamości regionalnych. Takie działania są naturalną konsekwencją występujących różnic. Współczesna koncepcja państwa hiszpańskiego zakłada pielęgnowanie świadomości regionalnej społeczności zamieszkujących jego terytorium, ale w ramach jedności państwa i narodu hiszpańskiego. Pytanie, które wymaga dalszej analizy, dotyczy tego, czy działania rządów regionalnych mieszczą się nadal w tej koncepcji, czy też wychodzą poza nią.

\section{Literatura cytowana}

Biernacka Maja (2010), Od narodu do interkulturowości. Współczesne wyobrażenia na temat zasad życia zbiorowego w społeczeństwie hiszpańskim, „Pogranicze. Studia Społeczne", t. 16: 5-21.

Biernacka Maja (2016), Paradoks polityki tożsamościowej w Hiszpanii. Ambiwalencja Kościoła wobec odmienności językowej Basków za rząów Franco, „Kultura i Społeczeństwo", t. 60, nr 1: 51-65.

Caminos-Marcet José-María, Armentia-Vizuete José-Ignacio, Marín-Murillo MaríaFlora (2013), Terrorism in the Basque press (1990, 2000, 2008-2009). Analysis of newspaper editorials about ETA's fatal attacks, „Revista Latina de Comunicación Social”, nr 68, http://www.revistalatinacs.org/068/paper/967_Bilbao/RLCS_paper967en.pdf (17.02.2016).

Esarte Muniain Pedro (2001), Navarra, 1512-1530. Conquista, occupación y sometimiento militar, civil y eclesiástico, Pampeluna, Wydawnictwo Pamiela.

Fernández Alonso Isabel, Blasco Gil José Joaquín (2014), Press subsidy policies in Spain in the context of financial crisis (2008-2012): An analysis of the Catalan case, „Europen Journal of Communication", t. 29, nr 2: 171-187.

Głuszek Dagmara (2004), Media w baskijskiej wspólnocie autonomicznej, „Zeszyty Prasoznawcze", Kraków, Wydawnictwo Uniwersytetu Jagiellońskiego: 92-101.

Głuszek-Szafraniec Dagmara (2014a), Media regionalne we wspótczesnej Hiszpanii, (w:) Stanisław Michalczyk, Dariusz Krawczyk (red.), Media a środowisko społeczne. Dylematy teorii i praktyki, t. 3, Gliwice-Katowice, OLPRESS: 275-290.

Głuszek-Szafraniec Dagmara (2014b), Wpływ autonomii na rozwój mediów katalońskich i baskijskich, (w:) Małgorzata Adamik-Szysiak, Ewa Godlewska, Media mniej- 
szości, mniejszości w mediach, Lublin, Wydawnictwo Uniwersytetu Marii Curie -Skłodowskiej: 233-249.

Głuszek-Szafraniec Dagmara (2014c), Language and Media Policy of the Autonomous Communities in Spain - an Overview of selected Regions in Spain, (w:) Ю.B. Лучинский, Ю.О. Гараев, А.Ф. Горбуненко, З.Ш. Кидакоева, А.Л. Факторович, M.А. Шахбазян (red.), Медийные стратегии современного мира, Krasnodar Wydawnictwo Kubańskiego Uniwersytetu Państwowego w Krasnodarze: 82-94.

Hallin Daniel C., Manicni Paolo (2007), Systemy medialne. Trzy modele mediów i polityki w ujęciu porównawczym, tłum. Marta Lorek, Kraków, Wydawnictwo Uniwersytetu Jagiellońskiego.

Jachimowski Marek (2006), Regiony periodycznej komunikacji medialnej, Katowice, Wydawnictwo Uniwersytetu Śląskiego.

Kieniewicz Jan (2001), Hiszpania w zwierciadle polskim, Gdańsk, Novus Orbis.

Kornacka Monika (2014), Portale internetowe jako narzędzie kształtujące tożsamość regionalna mieszkańców - na przykładzie Śląska Cieszyńskiego, (w:) Stanisław Michalczyk, Dariusz Krawczyk (red.), Media a środowisko społeczne. Dylematy teorii i praktyki, t. 3, Gliwice-Katowice, OLPRESS: 240-256.

Kuś Michał (2013), Telewizja publiczna w Hiszpanii. Pomiędzy polityka i rynkiem, Wrocław, Wydawnictwo Uniwersytetu Wrocławskiego.

Lorenzo Suárez Anxo M., Ramallo Fernando, Casares Berg Håkan (2008), Lingua, sociedade e medios de comunicación en Galicia, Santiago de Compostela, Consello da Cultura Galega.

Nguyen Eric (1998), Les Nationalismes en Europe. Quête d'identité ou tentation de repli?, Paryż, Wyd. Le Monde/Editions Marabout.

Patek Artur, Rydel Jan, Węc Janusz Józef (red.) (2005), Najnowsza historia świata 19631979, t. 2, Wydawnictwo Literackie, Kraków.

Pietraś Jacek Ziemowit (1995), Uczestnicy stosunków międzynarodowych, (w:) Łoś-Nowak Teresa (red.), Współczesne stosunki międzynarodowe, Wrocław, Wydawnictwo Uniwersytetu Wrocławskiego: 39-50.

Pisarek Walery (2007), O mediach i języku, Kraków, Universitas.

Sadowski Andrzej (2011), Socjologia wielokulturowości jako nowa subdyscyplina socjologiczna, „Pogranicze. Studia Społeczne”, t. 18: 5-25.

Urzainki Tomás, Olaizaola Juan María (2000), La Navarra marítima, Pampeluna, Wydawnictwo Pamiela.

Waldenberg Marek (2000), Narody zależne i mniejszości narodowe w Europie Środkowo -Wschodniej. Dzieje konfliktów i idei, Warszawa, Wydawnictwo Naukowe PWN.

Wojcieszak Łukasz, Głuszek-Szafraniec Dagmara (2011), Ewolucja ustroju polityczno-terytorialnego Hiszpanii (1975-2010). Przykład Kraju Basków, Katalonii i Galicji, Bielsko-Biała, Wyższa Szkoła Administracji. 


\section{Inne źródła}

Agenda Estratégica del Euskera 2013-2016. Una lengua viva para la convivencia, (Strategiczna Agenda dla języka baskijskiego 2013-2016. Żywy język dla koegzystencji), https://www.irekia.euskadi.eus/uploads/attachments/4892/Agenda_Estrategica. pdf?1403612013 (23.02.2016).

Alós Ernest, 'Star Wars' en catalán: 30 cines, pero pocas butacas („Star Wars” po katalońsku: 30 kin, ale niewiele miejsc), „El Periódico”, 17.12.2015, http://www.elperiodico.com/es/noticias/ocio-y-cultura/star-wars-doblada-catalan-4759953 (13.02.2016).

Boletín Oficial del País Vasco (Oficjalny Biuletyn Kraju Basków), 30.12.2015, nr 248 http://www.euskara.euskadi.eus/r59-738/es/bopv2/datos/2015/12/1505507a.pdf (23.02.2016).

La Corporació Catalana de Mitjans Audiovisuals (Katalońska Korporacja Mediów Audiowizualnych), http://www.ccma.cat/corporatiu/es/el-grup/\# z dnia 23.02.2016.

CIES (Informacyjne Centrum Statystyk i Sondaży), http://www.ciessl.com/imagenes/13. pdf (02.03.2016).

V Encuesta Sociolingüística 2011. País Vasco, Comunidad Autónoma Vasca, Navarra, País Vasco Norte (2013), Comunidad Autónoma del País Vasco, Departamento de Educación, Política Lingüística y Cultura, Vitoria-Gasteiz 2013, (V Ankieta Socjolingwistyczna 2011. Kraj Basków, Baskijska Wspólnota Autonomiczna, Nawarra, Północny Kraj Basków), http://www.euskara.euskadi.eus/contenidos/informacion/argitalpenak/es_6092/adjuntos/VEncuesta.pdf (12.01.2016).

El Parlament modifica la ley de normalización lingüística en fomento de catalán, „Diario de Mallorca”, (Parlament zmienia ustawę o normalizacji językowej na rzecz promocji katalońskiego, „Dziennik Majorki”) 26.01.2016, http://www.diariodemallorca.es/mallorca/2016/01/26/parlament-modifica-ley-normalizacion-linguistica/1088661.html (13.02.2016).

Enquesta de consum i pràctiques culturals de Catalunya 2001 (2003), Generalitat de Catalunya, Departament de Cultura-Institut d'Estadística de Catalunya-ECPC/2001, Barcelona, (Ankieta na temat praktyk kulturalnych 2001, Instytut Statystyki Katalonii) http://www.idescat.cat/cat/idescat/publicacions/cataleg/pdfdocs/ecpc2001. pdf (13.02.2016).

Enquesta de consum i pràctiques culturals 2006 (2008), Generalitat de Catalunya, Institut d'Estadística de Catalunya, Barcelona, 2a versió corregida el 24 d'octubre del 2008 (Ankieta na temat praktyk kulturalnych 2006, Instytut Statystyki Katalonii, wersja poprawiona z 24.10.2008) http://www.idescat.cat/cat/idescat/publicacions/ cataleg/pdfdocs/ecpc06.pdf (13.02.2016).

Euskal Irrati Telebista (Baskijska Rozgłośnia Radiowo-Telewizyjna), http://www.eitb.eus/ es/ (15.01.2016).

Evolución de la población de 16 y más años de Euskal Herria por territorio y grupo de edad según competencia lingüística. 1991-2011, Eustat, (Ewolucja kompetencji językowych ludności Kraju Basków powyżej 16 roku życia według terytorium i grupy wiekowej w latach 1991-2011), http://www.eustat.eus/ elementos/ele0009500/ 
ti_evolucion-de-la-poblacion-de-16-y-mas-anos-de-euskal-herria-por-territorio -y-grupo-de-edad-segun-competencia-linguistica/tbl0009564_c.html\#axzz40W1DzGhN (18.02.2016).

Informe de política lingüística 2013, Generalitat de Catalunya, Departament de Cultura, (Informacja o polityce językowej 2013, Departament Kultury Rządu Katalońskiego), http://web.archive.org/web/20141114144947/http://www20.gencat.cat/docs/ Llengcat/Documents/InformePL/Arxius/IPL_2013.pdf (18.02.2016).

Konstytucja Hiszpanii z dnia 27 grudnia 1978 r. wraz z ostatnią zmianą z 27 sierpnia 1992 r., http://libr.sejm.gov.pl/tek01/txt/konst/hiszpania.html (18.02.2016).

Ley 10/1982, de 24 de noviembre, Básica de normalización del uso del Euskera (Ustawa o normalizacji używania języka baskijskiego), https://www.boe.es/boe/ dias/2012/04/26/pdfs/BOE-A-2012-5539.pdf (23.02.2016).

La Ley 1/1998, de 7 de enero, de Política Lingüística (Ustawa o polityce językowej), https:// boe.es/diario_boe/txt.php?id=BOE-A-1998-2989 (13.02.2016).

Más vascos saben euskara, pero se habla menos en los hogares (Więcej Basków zna baskijski, ale mniej mówi nim we własnym domu), 7.04.2014, „El País”, http://ccaa. elpais.com/ccaa/2014/04/07/paisvasco/1396871575_554877.html (23.02.2016).

Medios de comunicación, Trabajo de campo 3-10/10/2011 (Media, badania terenowe 3-10.2011, Biuro Badań Socjologicznych), Gabinete de Prospección Sociológica, luty 2012, http://www.lehendakaritza.ejgv.euskadi.eus/contenidos/ informe_estudio/o_11monol_medios/es_11medios/adjuntos/11monografico_es.pdf (29.02.2016).

Oficina de Justificación de la Difusión (Biuro Kontroli Dystrybucji Mediów), http://www. introl.es/medios-controlados/? (01.03.2016).

Plan de Acción para la Promoción del Euskera, Consejo Asesor del Euskera (Plan Działania na rzecz promocji języka baskijskiego, Rada Doradcza Języka Baskijskiego), http://www.euskara.euskadi.eus/contenidos/informacion/esep_sarrera/es_esep/ adjuntos/Plan\%20de\%20Accion\%20para\%20la\%20Promocion\%20del\%20Euskera\%20(ESEP).pdf (23.02.2016).

Rubió Marthe, 181 milliones para los medios en pleno proceso soberanista (181 milionów na media zaangażowane w proces niepodległościowy), „El Mundo” http:// www.elmundo.es/grafico/espana/2014/09/08/53db717bca4741781c8b4577.html (14.01.2016). 
StreszCZENIE

Hiszpania jest państwem składającym się z 17 wspólnot autonomicznych, które posiadają własne kompetencje w dziedzinie polityki wewnętrznej. Niektóre rządy regionalne wykorzystują więc przyznane im narzędzia i środki w celu kształtowania własnych koncepcji budowania społeczeństwa. Od czasu przyznania autonomii władze Katalonii i Kraju Basków rozpoczęły budowę niezależnych systemów komunikacji masowej. Celem artykułu jest przedstawienie, jak media regionalne przez modele zarządzania i system subwencji stały się częścią polityki tożsamościowej regionalnych rządów.

\section{Słowa kluczowe:}

tożsamość regionalna, media regionalne, polityka medialna, Kraj Basków, Katalonia.

SUMMARY

\section{Media policy in Catalonia and the Basque Country as an instrument for the development of regional identities}

Spain is a state consisting of 17 autonomous communities; each of them has its own competences in the area of internal policy. Thus, some of the regional governments use the tools and the means, granted as a part of their autonomy, to create their own concept of building a society. Since the autonomy is granted to Catalonia and the Basque Country, their local governments started to build their separate systems of mass communication. The aim of the article is to present, how the regional media became a part of a broader identity policy, by applying management models and subvention systems.

\section{Keywords:}

regional identity, regional media, media policy, Basque Country, Catalonia. 